\title{
A Narrative Review on Legal Aspects of Older People in Albania
}

\author{
Nertila Podgorica
}

Ph.D. Candidate, Researcher, Department of Nursing Science and Gerontology, UMIT - Private University for Health Sciences, Medical Informatics and Technology,

Hall in Tyrol, Austria; Nursing Department, Fh Gesundheit I Health University of Applied Sciences Tyrol, Austria; Nursing Department, Faculty of Natural Sciences, University of Shkodër "Luigj Gurakuqi", Albania

\section{Blerta Zenelaj}

Ph.D. Researcher, Faculty of Law, University of Leiden, Netherlands

\section{Daniela Deufert}

Priv.-Doz. Dr., Department of Nursing Science and Gerontology, UMIT - Private University for Health Sciences, Medical Informatics and Technology, Hall in Tyrol, Austria

\section{Michael Ganner}

Univ. Prof. Dr., Institut für Zivilrecht Universität Innsbruck, Austria

\section{Magdalena Flatscher-Thöni}

Assist.-Prof. Dr. , Institute of Public Health, Medical Decision Making and Health Technology Assessment, Department of Public Health, Health Services Research and Health Technology Assessment, UMIT - Private University for Health Sciences, Medical Informatics and Technology, Hall in Tyrol, Austria

DOI: https://doi.org/10.36941/jesr-2020-009o

\section{Abstract}

Older people over the world have been confronted with challenges such as poverty, discrimination, and abuse, hindering their human rights and their place in society. However, the world has not tackled this challenge with urgency. While concerns associated with older people are not a new phenomenon, they have been perceived as challenges that warrant solutions that are operational, reactive, and piecemeal. This is particularly true in the case of Albania. Although older people have been historically ignored by human rights law, their rights and legal aspects are now emerging as an integral part of public policies. Within this frame, our review explores the legal aspects of older people in Albania. From the findings, it has been revealed that although there are laws ensuring legal aspects of elderly people in Albania, they have not been effectively implemented. There is a huge need to effectively implement legal support and rights for older people in Albania.

Keywords: older people, legal aspects, human rights, law 


\section{Introduction}

Over the last few decades, people worldwide have been living longer, and the proportion of citizens over 6o years old is outpacing any other age group. The results of both include longer life expectancy and declining fertility rates (Clement, 2013; WHO, 2015). According to the World Health Organization (2015), by 2050, the world's population aged 6o years and older, is expected to reach 2 billion, compared to 900 million in 2015. By 2050, the number of people 65 years or older will globally be higher than the number of individuals aged 15 to 24 years (DESA, 2019).

Europe has the highest proportion of the elderly population among other world regions, specifically, Albania has been experiencing the effects of population ageing. The median age of the population is increasing, and in 2060, half of the Albanian population is expected to be older than 50 (INSTAT, 2015). According to the 2015 census, in Albania, the population aged over 65 was 318,ooo in 2011, and it is expected to reach 667,000 in 2060 (INSTAT, 2015, 2019).

Alongside this increased life expectancy, elderly people suffer from specific health conditions. Ageing is an inevitable process (UN, 2018), which is viewed from different aspects: biological, psychological, and social structures of individuals. In addition, ageing involves psychosocial changes that influence functional capacity, social involvement, and physical, and mental health (Miller, 2010; WHO, 2017). In Albania, the elderly is one of the most vulnerable groups in society, facing a lot of challenges, especially various social barriers, and often do not receive proper healthcare services (ASAG, 2015). Elderly Albanians are increasingly living alone, left behind by migrating adult children, and suffer from reduced economic self-sufficiency wherein they cannot afford their everyday needs, including their medications (ASAG, 2015). In fact, elderly people with severe health problems are often admitted to hospitals, and in the absence of family caregivers, a growing number of elderly persons still find themselves facing physical and social isolation along with abuse and violence.

In Albania, support for the elderly is regulated through legislative measures, such as laws regarding basic pensions (Demi, 2015), but mainly, the elderly, are disregarded in public debate. In fact, Albania does not yet have comprehensive policies on ageing (ASAG, 2015), A draft legislation was passed to allocate funds and resources for the involvement of older people (ASAG, 2015; PozueloMonfort, 2016) but unfortunately, due to the lack of political will, the prioritization of special rights has often been at older Albanians' expense.

This paper aims to provide a comprehensive review of the legal aspects related to Albanian elderly people.

\section{Methodology}

A narrative review of literature was conducted to examine this research question: To what extent does the legislative framework in Albania empower, include, and protect the elderly population? An iterative process of defining appropriate terms, reviewing the literature, and synthesizing the findings was used. Initial research regarding articles was carried out through the Google Scholar and Scopus citation databases to identify relevant papers related to legal issues pertaining to older people in Albania. As narrative reviews are not that systematic via the searching process (Green et al., 2006), different papers were found from the references of the previous ones and were included in this review.

The literature search was conducted using Boolean keyword combinations "(Legal aspects OR Law OR Legislation) AND (Elderly persons OR Older persons)." The keywords used were "Aged”, OR "older persons", AND "jurisprudence", OR “international framework" OR "law", OR "legal”, AND "Albania", between 2000 and 2019. We further reviewed the reference lists of selected articles for additional academic papers on the topic. Only articles that focused on legal issues related to elderly people in Albania, published in English or Albanian as full text between January 2000 and May 2019, were included.

This review provides the broad scope of the topic, following guidelines described in previous 
publications (Green et al., 2006). The findings serve as a useful legal tool, while it is important to note that the main limitation of narrative review lies in the unsystematic search method, which may lead to the subjective selection of articles and consequently add bias to the overall interpretation of the findings. Considering this limitation in the search strategy, but with the limited evidence in the literature, this overview was as thorough as possible.

\section{International Human Rights Framework for Older Persons}

The basic framework for the legal aspects of ageing comprises the fundamental rights and international standards, which are derived from human rights instruments established by the United Nations (UN) (Martin et al., 2015; Miller, 2010; OHCHR, 2012), including treaties, conventions, General Comments, and protocols. Albania has been a UN member state since 14 December 1995 and has ratified almost all its significant conventions related to the protection of fundamental human rights. Since 13 July 1995, Albania is a state member of the Council of Europe (CoE) and has ratified a considerable number of important conventions approved by it. In addition, Albania aims to become a member state of the European Union (EU) and is working on harmonization of its legislation according to EU standards.

The Universal Declaration of Human Rights (UDHR) is the first international instrument for the protection of human rights for everyone with no discrimination of any kind (UNGA, 1948). Article 25 guarantees the right to health of older people, mentioning food, housing, shelter, and security. The UDHR was adopted by the UN General Assembly and ratified by Albania.

The International Covenant on Civil and Political Rights (ICCPR) (UNGA, 1966a) is a treaty adopted by the UN General Assembly, monitored by the Human Rights Committee (HCR), and protected by the Human Rights Council (HR Council). It guarantees the civil and political rights, such as the right to life, movement, and association, the right not to be subjected to torture, slavery, etc. Article 26 of the ICCPR states that everyone is equal before the law and grants the equal protection of the law, without any discrimination. Although elderly people are not explicitly mentioned, this applies to them as well. (UNGA, 1966a).

The Republic of Albania has ratified and adhered to the International Covenant on Civil and Political Rights (ICCPR) by approval of Law No. 7511/08.08.1991 and its Protocols by Law No. 9725/07.05.2007 and Law No. 9726/07.05.2007.

The International Covenant on Economic, Social, and Cultural Rights (ICESCR) was ratified in Albania on 04.10.1991. ICESCR protects the economic, social, and cultural rights of all humans, including the elderly. Moreover, the ICESCR recognizes the right of everyone to the highest standards of physical and mental health, including older people (Article 12) ("The International Bill of Human Rights," 2003). Taking into consideration this article, medical training and professional programs in geriatric healthcare services should be encouraged.

The International Convention on the Elimination of All Forms of Racial Discrimination (ICERD) (UNGA, 1965) was ratified in Albania on 11.05.1994 and promotes prohibition and elimination of all forms of racial discrimination for all people in order for them to enjoy all rights and freedoms on an equal basis as others (ICERD article 5). The Convention on the Elimination of all Forms of Discrimination against Women (CEDAW) was ratified in Albania in 1993 by Law No. 1769/o9.11.1993. Article 11 requires the elimination of discrimination against women, guaranteeing equality between women and men regarding the right of social security for old people. The right to social security should be granted in case of retirement, disability, sickness, and old age. (CEDAW, Article 11, paragraph 1(e)) (UNGA, 1979). Special attention is given to older women and protection of their rights (CEDAW, General Recommendation No. 27, paragraph 2, 2010). Since women tend to live longer than men, they often end up living alone (CEDAW, General Recommendation No. 27, paragraph 5, 2010).

The United Nations Convention on the Rights of Persons with Disabilities (UNCRPD) was ratified by Albania as Law No. 108/2012. Article 25 of the UNCRPD reaffirms the right to the highest 
attainable standard of health without discrimination based on disability for all people, including older people with physical or mental disabilities (UNGA, 2006). Older people with disabilities should enjoy the right to various social protection programs as well as poverty reduction programs (UNCRPD Article, 28 paragraph $2(\mathrm{~b})$ ). The state parties should provide age-appropriate assistance to realize all human rights and freedoms, and age-sensitive programs should be broadcasted.

Further protection of the fundamental rights of elderly is granted from the General Comments ("The International Bill of Human Rights," 2003; UNGA, 1966b). The most relevant General Comments regarding elderly people are: General Comment No. 4 on The Right to Adequate Housing (CESCR, 1991) and General Comment No. 5 under Article 3 on the Rights of Persons with Disabilities (ECOSOC, 1994). All these comments underline that all state parties (including Albania) of ICESCR are obliged to pay special attention to the economic, social, and cultural rights of elderly people. (ECOSOC, 1999).

General Comment No. 14 on The Right to the Highest Attainable Standard of Health (The Right to Health) is an important issue in the life of elderly people. The General Comment No. 14 imposes that health services for elderly people should be available in sufficient quantities within the respective countries, as well as accessible, non-discriminatory, and affordable. In addition, health services, goods, and services for elderly people should be acceptable regarding cultural, medical ethics, gender sensitivity, and confidentiality. Moreover, health facilities, goods, and services for older people should be scientifically and medically appropriate, which implies continuous training for the staff of the hospitals or residential homes according to international standards (General Comment No. 14, paragraph 12). Depending on the health condition, integrated approaches should include personalized physical and psychological treatments, continuous check-ups, and the right to die with dignity (General Comment No. 14, paragraph 25).

\subsection{The rights of elderly people under the European legislative framework}

Human rights at European level are protected by two major political structures: The CoE and the EU. Albania became the 35th Member State of the CoE on July 13, 1995. The European Convention for the Protection of Human Rights and Fundamental Freedoms (ECHR) (CoE, 1950) protects civil and political rights and was ratified by Albania on 04.06.1998. It does not explicitly protect older peoples' rights, but the rights under this treaty protect all individuals. The ECHR is protected by the European Court of Human Rights (ECtHR) which functions as a constitutional court for older people who might face violation of their rights and freedoms (CoE, 1950). The jurisprudence of ECtHR has dealt with many cases of elderly people, taking into consideration many articles such as the right to life (Article 2), prohibition of the torture and inhuman or degrading punishment or treatment (Article 3 ), the right to a fair trial (Article 6), the right to respect for a private and family life (Article 8) of the ECHR, etc.

Since older people may face different health conditions, they are also treated and protected as patients. An important aspect of the European challenge concerns how to develop healthcare systems based on values enshrined in the ECHR and the European Social Charter (CoE, 1950, 1996). In this framework, many international events were aimed at the improvement of the rights of the patients through the European Consultation on the Rights of Patients, convened under the auspices of the WHO Regional Office for Europe (WHO/EURO), and hosted by the Government of the Netherlands (1994). As a result, the patients' rights are explained in the Principles of the Rights of Patients in Europe (WHO, 1994), based on international and regional treaties and conventions. At the European level, ECHR influences patients' rights by the EU's Fundamental Charter of Human Rights (EU, 2012).

The European Revised Social Charter was adopted initially in 1996 (CoE, 1996). Albania ratified the Charter on 14.11.2002 and has accepted 64 of its 98 articles. Its incorporation into domestic law is based on Article 122 of the Albanian Constitution. The importance of the Charter is that it explicitly addresses the rights of elderly people (Article 23). This article overlaps other articles of the Charter that protect elderly people as part of the entire population. 
In 2014, the Committee of Ministers of the CoE adopted a specific recommendation to member states on the promotion of human rights of older people. This recommendation takes into consideration the ECHR (the European Social Charter) and the Biomedicine Convention, which states that older people are entitled to the rights set in the ECHR and to other human rights instruments (Article I, paragraph 3) (CoE, 2014b). Furthermore, the Charter ensures the right of older people to enjoy their rights and freedoms without discrimination on any grounds (Article II).

In addition, the elderly have the right to receive benefits from their states through appropriate measures for prevention, promotion, maintenance, and improvement of their health and well-being (Article VI). States should also ensure that appropriate healthcare and long-term quality care are available and accessible. Older people have the right to receive medical care based only upon their free and informed consent and may withdraw such consent at any time. If they do not have the capacity to consent to an intervention, particularly due to a mental disability or disease, interventions may only be carried out with the authorization of their representatives or authority provided by law. Older people placed in institutional care have the right to freedom of movement. Any restrictions must be lawful, necessary, proportionate, and in accordance with international law. Any older person in need of palliative care should be entitled to access it without undue delay in a setting that is consistent with his or her needs and preferences, including at-home and in long-term care settings (CoE, 2014b; Martin et al., 2015). Many parts of this recommendation are part of other treaties and conventions, but Albania still is having problems in complying with the rights and freedoms of older people.

To better respond to the new developments of science and medicine, many human rights were elaborated to protect the dignity of people during a health intervention. These rights were included in the European Convention for the protection of Human Rights and Dignity of the Human Being with regard to the Application of Biology and Medicine (Biomedicine Convention or Oviedo Convention) (Nys et al., 2007), and were ratified by Albania on 30.03.2011.

The Biomedicine Convention protects the integrity and dignity of all human beings without discrimination in application of biology and medicine (Biomedicine Convention, Article 1). For the first time, the Biomedicine Convention grants the right to consent and special protection for people who are not able to consent before any health intervention (Biomedicine Convention, Article 6) and the need to honor the previously expressed wishes for patients who are not, at the time of health intervention, able to consent or to express his/her wishes, such as those with dementia who wish to die in dignity (Biomedicine Convention, Article 9).

\subsection{European Union Instruments}

The most important human rights document of the EU is the Charter of Fundamental Rights of the European Union (EU, 2012), which applies to the member states of the EU and protects civil, political, economic, and social rights. It protects older people's rights within Article 25 "... the right to lead a life of dignity and independence and to participate in social and cultural life". This article conforms with the international and European important human rights treaties and conventions (CoE, 1996; EU, 2012; Martin et al., 2015; OHCHR, 2012). In addition, on the EU level, it has adopted the European Charter of Patients' Rights (ACN, 2002). This charter is based on the "high level of human health protection" (Article 35 of the Charter of Fundamental Rights of the European Union), aiming to ensure high quality of services provided by various national health services within the EU. All these rights are fundamental to European citizens and healthcare services, applying to all individuals, recognizing that differences such as age, gender, religion, and socioeconomic status may influence individual healthcare needs (ACN, 2002 Article 35).

\subsection{Legal Aspects of Albania}

There are distinctive challenges faced by elderly people in Albania. This is an overview of the current 
legislative framework and its protection for this target group.

Albania is a member state of the UN and CoE but not yet part of the EU. Albania has ratified all the necessary conventions and recommendations and protects human rights in the Constitution by numerous individual laws. According to the Constitution of the Republic of Albania (Article 122/1), "Any international agreement that has been ratified constitutes part of the internal juridical system upon its publication in the Official Gazette of the Republic of Albania" (AL, 2008). Therefore, based on this article of the Constitution, all the treaties and conventions ratified by Albanian's government are part of the legislative framework of the country and should be obligatory for everyone and every institution.

The Albanian Constitution (1998, amended) provides the right to healthcare to all citizens with no discrimination of any kind. It further states, "Citizens enjoy equally the right to healthcare from the state, and everyone is entitled to healthcare insurance" (Article 55, AL, 2008). In addition, Article 59 in the chapter of Social Objectives emphasizes to also encourage private institutions towards the employment of all people able to work; to meet the needs of citizens for housing; the highest standard of health, physical and mental potential; the care and help for the elderly, orphans and the disabled; health rehabilitation, specialized education, and integration in society of disabled people, as well as continual improvement of their living conditions (AL, 2008).

Different issues on elderly social care are regulated in Albanian legislation through Law No. 9355/10.03.2005 on "Social Assistance and Services' ' (AL, 2005). Within this law, the elderly people are defined as "person[s] who have[have] reached retirement age under the legislation in force" (Art. 4, para. 16). In addition, Article 6 of this law declares that the beneficiaries of Albanian social services are "children, youths up to the age of 25, the elderly, people with disabilities, women, girls in need, and all other vulnerable groups likely to fall into the category of groups in need" (AL, 2005). There are provisions made for these protected groups in terms of social services delivered.

However, in Albania, although the legislation does not impose gender norms, the family system is very patriarchal in values and customary laws mostly dominate in rural areas, accompanied by the risk of relegating women in general and older women in particular to a marginal role (Mangiavacchi et al., 2018). Law No. 93/2014, "For the inclusion and accessibility of disabled people" (AL, 2014a), stipulates that among other things, the law is founded based in the principle of participation of people with disabilities on the basis of active involvement and individual consultation of people with disabilities. Law No. 9669/18.02.2006, "On measures against domestic violence" revised, aims to prevent and reduce all forms of violence, through appropriate legal measures, in order to guarantee human rights protection for family members who are victims of domestic violence, with special attention to elderly and people with disabilities (AL, 2006).

The elderly's health protection in Albania is further guaranteed with Law No. 10107/30.03.2009 "On Healthcare" as amended by Law No. 27/2019. It states the provision of primary healthcare without any restrictions arising from disease, age, gender, economic status, or categories of patients (Chapter 3, Article 9, paragraph 3). In other words, the Albanian primary healthcare meets the required needs for basic medical treatment, nursing care, prevention, and rehabilitation, when these do not require treatment and examination techniques, provided by other levels of healthcare" (AL, 2009, 2019).

According to Dhar (2011), the quality of life among elderly people in rural areas is lower than that in urban areas. Research findings reveal that the services provided by the government and some nongovernmental organizations, such as residential homes and daycare centers, are located far from rural elderly patients, who therefore do not have access to such services (MSHMS, 2019). Albanian state services are not prepared and are not in position to expand the required level of care services for all the elderly people all over the country. As such, a general paucity of care has been observed in terms of specialized institutions for elderly people (Lerch, 2016). Article 23 which represents an important essential provision related to the rights of elderly people, has still not been ratified by Albania. In addition, the Law No. 121/2016 "On social care services in the Republic of Albania", the "National Report of Albania regarding the Madrid Plan 2016", and the Strategy of Social Protection 
and Inclusion 2019-2022, are highlighting age as a risk factor that should be taken in consideration and especially "aged woman" as a specific category (AL, 2016; Ylli et al., 2016) as underlined in the international and European Conventions. This is also in line with international conventions and General Comments.

Law No. 138/2014 "On Palliative Care in the Republic of Albania" in its article 26 on social support states the necessity of the terminally ill people to receive a payment, regardless of age and the income earned by the state (Article 26, AL, 2014b). The amount and the criteria of receiving this payment are determined by the official decision of the Albanian Council of Ministers, considering the proposal of the Minister of Health and the Minister of social affairs.

In the framework of becoming a member state of the EU, Albania is introducing new laws, regulations, and packages of services, which include several reforms and provisions in healthcare (Arqimandriti et al., 2014). The new package of services aims to provide system-based primary healthcare for all Albanians, focusing on healthcare for older people, reducing complications, and maintaining their good mental and physical health (Section 5).

Patients' rights are described in the Albanian Patients' Rights Card (Karta Shqipëtare E Të Drejtave Të Pacientit, 2010) (AL, 2010a), and protected by the healthcare law (Law No. 10107). This is a particularly important document, especially for elderly people who are admitted to hospitals. Albanian National Health Strategy 2016-2020 is another document related to the elderly's protection. The Albanian government is focused on finding and executing solutions to different challenges in healthcare that are impacted by an array of factors that are economic, social, and environmental in nature and those that were interlinked at regional, local, national, and global levels (Health, 2019). Handling the present challenges in healthcare warrants the need for coordinated actions as well as strategies in the system of health across all sectors. Keeping these aspects in mind, the Albanian Ministry of Health elaborated on the National Health Strategy 2016-2020, which coordinates all the initiatives towards enhancing the well-being and health of the population of Albania (Health, 2019), including the elderly.

\section{Current Gaps and Future Research Opportunities}

As was mentioned above, there is no convention at an international or regional level that specifically protects the rights of elderly people. To respond better to the needs of the elderly people and to better interpret their rights, perhaps, it is time for an international convention that focuses on the rights of this target group. On the national level, the Albanian legal framework does not offer specific protection for safeguarding the fundamental human rights and freedoms of elderly people. Although Albania has ratified the European Social Charter, the article related to the elderly (Article 23) has not yet been accepted. Still, there are many other international and regional conventions that Albania is part of; therefore, the protection of the rights of older people should be guaranteed. There are neither institutions for long-term care nor facilities to treat elderly dementia. Standards of elderly care are at a minimum level (ASAG, 2015).

The 2005 Human Development Report for Albania confirms that elderly people often live alone and are at high risk for social abandonment (UNDP, 2005). Consequently, this reinforces a sense of depression (De Soto et al., 2002). In addition, the pensions received by the elderly in Albania are small and are mainly derived from work done by the individual under the communist economic system prior to 1990. Therefore, most elderly in Albania are highly financially dependent on their children (King et al., 2014).

In Albanian universities' curricula, geriatric care has been recently introduced. There is a lack of continuous education for healthcare professionals. Specific training is needed, focusing on communication, ethical issues, and human rights in geriatric care (Ylli et al., 2016). Updated university teaching regarding geriatric care is further needed as well as the implementation of social and healthcare standards for the elderly in residential and day-care centers.

The creation of a new international convention should focus on the rights and freedoms of older 
people worldwide. On the national level, a specific law based on international and European standards for the elderly is required.

Small, Siewert, and Porrazzo (2015) observed that the elderly population in Albania is projected to increase by $40 \%$ in the next two decades. They expressed concern that the Albanian economy would not be able to withstand the dual impacts of the costs of caring for an increasingly elderly population and the reduction in the workforce (Small et al., 2015). Allamani (2015) examined the social security/pension system in Albania, considering difficulties that might present themselves as the country transitioned to a free-market economy. He concluded that due to the global financial crisis and economic growth slowdown, there was an overall increase in poverty, which constitutes a challenge for the reform of social protection schemes. The aging of the population would only make the problem worse as time goes on (Allamani, 2015).

Conkova, Vullnetari, King, and Fokkema (2018) compared the situation of the elderly people in Albania and Bulgaria, two former communist countries that are still struggling with the transition from a Soviet-style economy to a free-market system. Conkova et al. (2018) observed that the problem of elder care was much more acute in these countries than elsewhere in Europe, even though the age demographics were roughly the same. This is because family members migrated elsewhere in Europe for employment and abandoned older family members. Thus, the elderly often had to fend for themselves. Pensions are inadequate to provide for the necessities of life and the elderly often face life-threatening hardships (Conkova et al., 2018).

For elderly people, the monthly pension is not enough to afford the private medical institutions or expensive drugs needed. This issue is widespread in rural areas, where healthcare facilities for elderly people are limited or non-existent. Over $60 \%$ of older people live in rural areas. According to Ylli (2010), Albanian elderly people face problems regarding affordability and accessibility of healthcare services due to the distance and high cost of medications for chronic illness. Faraway health centers, lack of public transportation, and lack of ICT technologies make the accessibility to health services difficult. According to INSTAT, there are around 400,0oo elderly people living in Albania (INSTAT, 2019). However, Dhamo stated that that percentage of the elderly is rising by about $1 \%$ a year and would level off at $20 \%$. Thus, Albania will soon be facing elder care problems in the same proportion as its European neighbors (Dhamo, 2014).

The literature suggests that elder healthcare in Albania will be a major issue in the next several years and will continue to be a concern for the foreseeable future. As one of Europe's less affluent countries, doing so could be an even greater challenge than that faced by the EU nations.

\section{Conclusion}

Albania is a developing country, steeped in older cultural values, including individual independence. Albania still has challenges implementing the international and European standards and is in the process of harmonizing its legislative framework with that of the EU. However, in order to ameliorate the general situation of the rights and freedoms of elderly people in Albania, the Albanian government should undertake steps in adopting all the necessary legislation at an international and European level.

Albania is lacking laws that are safeguarding elderly people. Moreover, the country is having problems enforcing its existing laws. This is one of the greatest challenges, which is creating a gap between the current legislation and Albanian practice. Irrespective of the many legal provisions available for elderly people in Albania, they are still struggling to obtain what they are legally entitled to. This can be attributed to social norms and the lack of a political will to enforce the existing laws. Though there are appropriate laws available, as evident in the sections above, there are no robust mechanisms to ensure whether elderly people have the power to exercise their legal rights. There is a need to alter the current approach regarding the legal rights of elderly people in Albania. More methods of helping to enforce such legal rights are very much required in the current situation.

Furthermore, more elderly-appropriate facilities are needed, not only in big cities but all over 
the Albanian territory. These facilities should fulfill the elderly needs not only in urban but also in rural areas.

\section{References}

Active Citizenship Network: European Charter of Patients' Rights, Presented in Brussels on 15 November 2002, 2016 C.F.R. (2002)

Republic of Albania the Assembly: Law no. 7703, dated 11.05.1993 "On Social Insurance in the Republic of Albania, (1993)

Republic of Albania the Assembly: Law No. 9355, Date 10.03.2005 On Social Assistance and Services., (2005)

Republic of Albania the Assembly: Law No. 9669 Dated 18.02.2006 On measures against domestic violence., Pub. L. No. 15.03.2018 (2006)

Republic of Albania: Amended Constitution of the Republic of Albania, 21 April 2008, (2008)

Republic of Albania the Assembly: Law No. 10107/30.03.2009, On Healthcare., (2009)

Republic of Albania the Assembly, Ministry of Health: Karta shqipëtare e të drejtave të pacientit, (2010a)

Republic of Albania the Assembly: Law No. 10221 dated 4.2.2010 On Protection From Discrimination, (2010b)

Albanian National Authorities: Law on Preventing and Combating Violence against Women and Domestic Violence, No. 104/2012 (2012)

Republic of Albania the Assembly: Law No. 93/2014, "For the inclusion and accessibility of disabled people". , (2014a) Republic of Albania the Assembly: Law No. 138/2014, On Palliative Care in the Republic of Albania, (2014b)

Republic of Albania the Assembly: Law No. 121/2016, On social care services in the Republic of Albania., (2016)

Republic of Albania the Assembly: Law No. 27/2019, On some amendments and additions to law no. 10 107, at (2019) 30.3.2009, On health care in the Republic of Albania, changed

Allamani, S. (2015). Social Protection and Support for Vulnerable Categories in Albania. Mediterranean Journal of Social Sciences, 6(2 S5), 393. Retrieved from https://www.mcser.org/journal/index.php/mjss/article/view/6205

Monitoring of the Primary Health Care System in Albania. USAID (2014)

Ministry of Health and Social Protection, State Social Service, Swiss Agency for Development and Cooperation SDC, UN Albania, UNDP Albania, Report: Assessment of the Need for Social Services in 12 District of Albania, p. 6 (Maj 2019)

ASAG. (2015). Older persons are an asset to and make a significant contribution to global development [Press release]. Retrieved from http://www.eurag-europe.net/wp-content/uploads/2015/11/ASAG-NewsletterNo.3.pdf

UN Committee on the Elimination of Discrimination Against Women (CEDAW), General recommendation No. 27 on older women and protection of their human rights, 16 December 2010, (2010)

UN Committee on Economic, Social and Cultural Rights (CESCR), General Comment No. 4: The Right to Adequate Housing (Art. 11 (1) of the Covenant), 13 December 1991, E/1992/23, (1991)

UN Committee on Economic, Social and Cultural Rights (CESCR), General Comment No. 6: The Economic, Social and Cultural Rights of Older Persons, 8 December 1995, E/1996/22, (1995)

UN Committee on Economic, Social and Cultural Rights (CESCR), General Comment No. 19: The right to social security (Art. 9 of the Covenant), 4 February 2008, E/C.12/GC/19, (2008)

Choi, M., Brownell, P., \& Moldovan, S. I. (2017). International movement to promote human rights of older women with a focus on violence and abuse against older women. International social work, 6o(1), 170-181

Clement, N. (2013). Nursing Ethics: Concepts, Trends and Practices. VSS College of Nursing, Bangalore, Karnataka: Pearson India

Council of Europe, European Convention for the Protection of Human Rights and Fundamental Freedoms, as amended by Protocols Nos. 11 and 14, 4 November 1950, ETS 5, (1950)

Council of Europe, European Social Charter (Revised), 3 May 1996, ETS 163, (1996).

Council of Europe, The Council of Europe Convention on Preventing and Combating Violence against Women and Domestic Violence, November 2014, ISBN 978-92-871-7990-6, (2014a)

Council of Europe: Committee of Ministers, Recommendation CM/Rec (2014)2 of the Committee of Ministers to member States on the promotion of human rights of older persons, 19 February 2014, CM/Rec(2014)2, (2014b)

Conkova, N., Vullnetari, J., King, R., \& Fokkema, T. (2018). "Left Like Stones in the Middle of the Road": Narratives of Aging Alone and Coping Strategies in Rural Albania and Bulgaria. The Journals of Gerontology: Series B

De Soto, H., Gordon, P., Gedeshi, I., \& Sinoimeri, Z. (2002). Poverty in Albania: a qualitative assessment: The World Bank 
Demi, A. (2015). Pension System in Albania. European Journal of Sustainable Development, 4(2), 393-400

United Nations, Department of Economic and Social Affairs, Population Division: World Population Prospects 2019, Highlights (ST/ESA/SER.A/423), (2019)

Dhamo, E. (2014). Albanian Ageing, Under the Education Perspective. ЕВРОДИЈАЛОГ Списание за европски прашања(19), 213-228

UN Committee on Economic, Social and Cultural Rights (CESCR), General Comment No. 5: Persons with Disabilities, 9 December 1994, E/1995/22, (1994)

UN Committee on Economic, Social and Cultural Rights (CESCR), General Comment No. 12: The Right to Adequate Food (Art. 11 of the Covenant), 12 May 1999, (1999)

UN Committee on Economic, Social and Cultural Rights (CESCR), General Comment No. 14: The Right to the Highest Attainable Standard of Health (Art. 12 of the Covenant), 11 August 2000, E/C.12/200o/4, (2000)

European Union, Charter of Fundamental Rights of the European Union, 26 October 2012, 2012/C 326/02, (2012)

EUSTaCEA project, under Daphne III programme: European Charter of rights and responsibilities of older people in need of long-term care and assistance, November 2010, (2010)

Fredvang, M., \& Biggs, S. (2012). The rights of older persons. Brotherhood of St Laurence and University of Melbourne Centre for Public Policy

Green, B. N., Johnson, C. D., \& Adams, A. (2006). Writing narrative literature reviews for peer-reviewed journals: secrets of the trade. Journal of chiropractic medicine, 5(3), 101-117

Albanian Ministry of Health: Albanian national health strategy 2016-2020 (2019)

Population Ageing: Situation of Elderly People in Albania, (2015)

Instituti i Statistikave: Popullsia e Shqipërisë, 1 Janar 2019, (2019)

The International Bill of Human Rights, 1 Cong. Rec. (2003)

King, R., Cela, E., Fokkema, T., \& Vullnetari, J. (2014). The migration and well-being of the zero generation: Transgenerational care, grandparenting, and loneliness amongst Albanian older people. Population, Space and Place, $20(8), 728-738$

Kohli, M. (2004). Intergenerational transfers and inheritance: A comparative view. Annual Review of Gerontology and Geriatrics, 24(1), 266-289

Lerch, M. (2016). Internal and international migration across the urban hierarchy in Albania. Population research and policy review, 35(6), 851-876

Mangiavacchi, L., Perali, F., \& Piccoli, L. (2018). Intrahousehold distribution in migrant-sending families. Journal of Demographic Economics, 84(1), 107-148

Martin, C., Rogriguez-Pinzon, D., \& Brown, B. (2015). Human Rights of Older People. (Vol. 45). Springer Dordrecht Heidelberg New York London: Springer Science+Business Media Dordrecht

Meçe, M. (2015). Population aging in Albanian post-socialist society: Implications for care and family life. SEEU Review, 11(2), 127-152

Miller, J. M. (2010). International Human Rights and the Elderly. Marquette Elder's Advisor,11(2).Retrieved from http://scholarship.law.marquette.edu/elders/volı1/iss2/6/

Ministria e Shendetesise dhe Mbrojtjes Sociale, Shqiperi: Plani kombetar i veprimit

mbi moshimin 2020-2025, Draft, (2019)

Nys, H., Stultiëns, L., Borry, P., Goffin, T., \& Dierickx, K. (2007). Patient rights in EU Member States after the ratification of the Convention on Human Rights and Biomedicine. Health Policy, 83(2-3), 223-235

Office of the High Commissioner for Human Rights. Normative standards in international human rights law in relation to older persons. Analytical Outcome Paper 2012, (2012)

Pozuelo-Monfort, J. (2016). Albania's Ageing Problem. Retrieved from https://www.huffpost.com/entry/albania-is-ageing_b_8191420

Sentell, T. L., Ylli, A., Pirkle, C. M., Qirjako, G., \& Xinxo, S. (2018). Promoting a Culture of Prevention in Albania: the "Si Je?" Program. Prevention Science, 1-11

Small, B. H., Siewert, G. A., \& Porrazzo, J. (2015). Evaluating Long-Term Health Care Options for the Elderly in Albania.

Political Declaration and Madrid International Plan of Action on Ageing. Second World Assembly on Ageing, Madrid, Spain 8-12 April 2002, (2002.

Promoting Inclusion through Social Protection. Report on the World Social Situation 2018, (2018)

United Nations General Assembly: The Universal Declaration of Human Rights (UDHR), Paris on 10 December 1948 (1948)

UN General Assembly, International Convention on the Elimination of All Forms of Racial Discrimination, 21 December 1965, United Nations, Treaty Series, vol. 66o, p. 195, (1965) 
UN General Assembly, International Covenant on Civil and Political Rights, 16 December 1966, United Nations, Treaty Series, vol. 999, p. 171, (1966a)

UN General Assembly, International Covenant on Economic, Social and Cultural Rights, 16 December 1966, United Nations, Treaty Series, vol. 993, p. 3, (1966b)

UN General Assembly, Convention on the Elimination of All Forms of Discrimination Against Women, 18 December 1979, United Nations, Treaty Series, vol. 1249, p. 13, (1979)

Report of the World Assembly on Ageing. Vienna International Plan of Action on Ageing Vienna ,26 July-6 August 1982 (resolution 37/51) (1982)

UN General Assembly, Implementation of the International Plan of Action on Ageing and related activities: resolution / adopted by the General Assembly, 16 December 1991, A/RES/46/91, (1991)

UN General Assembly, Convention on the Rights of Persons with Disabilities, 13 December 2006, A/RES/61/106, Annex I, (2006).

World Health Organisation: A Declaration on the Promotion of Patients' Rights in Europe. European consultation on the rights of patients, Amsterdam 28 - 30 March 1994, ICP/HLE 121, (1994)

European Ministerial Conference on Mental Health: Mental Health Declaration for Europe Facing the Challenges, Building Solutions, Helsinki, Finland, 12-15 January 2005, EUR/04/5047810/6. , (2005)

World report on ageing and health, (2015)

Global strategy and action plan on ageing and health. Geneva: World Health Organization; 2017. Licence: CC BYNC-SA 3.0 IGO., (2017)

Ylli, A., Xhafa, M., \& Proda, A. (2016). National Report on the Follow-Up to the Regional Implementation Strategy (RIS) of the Madrid International Plan of Action on Ageing (MIPAA) in Albania during the period 2012-16. Retrieved from https://www.unece.org/fileadmin/DAM/pau/age/country_rpts/2017/ALB_report_eng.pdf

Ylli, A. (2010). "Health and Social Conditions of Older People in Albania: Baseline Data from a National Survey" Public Health Reviews Vol. 32. No. 2, p. 558 